\title{
Please Stop Blabbing: A Prescription for Verbal Diarrhea
}

\author{
Victoria Chen
}

Humber College

DOI: $10.22329 /$ celt.v11i0.4960

Course instructors often rely on student participation to increase interaction and learning in the classroom. However, while verbalizing thoughts can help students learn, students in this study felt that frequency of contributions was often rewarded over quality. They called this "verbal diarrhea" and explained how prominent it was in their university learning experiences. In this Active Learning Classroom (ALC) study, students noticed "verbal diarrhea" was significantly reduced, making their learning more authentic. This paper presents "prescriptions" for verbal diarrhea; these may be useful for instructors using both ALCs and traditional teaching and learning spaces.

Dans leurs cours, les enseignants comptent souvent sur la participation des étudiants pour accroître le niveau d'interaction et d'apprentissage en classe. Toutefois, bien que le fait d'exprimer sa pensée puisse aider l'étudiant à apprendre, les sujets-étudiants de cette étude ont dit avoir le sentiment que l'on accordait davantage de valeur à la fréquence des contributions qu'à leur qualité. Ils ont employé l'expression de "diarrhée verbale "et ont expliqué la place prépondérante que ce phénomène occupe dans leur expérience d'apprentissage universitaire. Dans cette étude d'une classe d'apprentissage actif, les étudiants ont noté qu 'il y avait beaucoup moins de " diarrhée verbale ". En conséquence, leur expérience d'apprentissage était plus authentique. Cet article suggère des "remèdes " contre la diarrhée verbale, remèdes que les enseignants peuvent utiliser dans les classes d'apprentissage actif, dans l'enseignement traditionnel ou dans les espaces d'apprentissage..

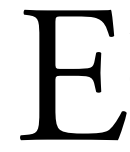

mployers look for people with university degrees, but why aren't they preparing us for the workplace?" one frustrated student expressed in the study. With higher education viewed as a "gateway" to the professional workplace (Rubenson, 2010), this student's disappointment with her learning experience is understandable. With lecture after lecture, students like this one expressed in this study how often they had to seek out part time jobs or part take in extra-curricular activities in order to gain experiences seen as "more useful." But why were classes not viewed in the same way by students? Many instructors would argue they were providing learning environments that prepare students for the workplace but maybe the teaching and learning strategies need to be re-examined from the students' perspectives.

With the paradigm of student-centred teaching and learning trending across universities and colleges, it is important to reflect on the common practices used and hear from students on their perspectives and experiences with the teaching 
approaches. This study focused on upper year students' learning, with the students reflecting on their lived experiences in the newly popular Active Learning Classrooms (ALCs) (Beichner, 2014; Cotner, Loper, Walker, \& Brooks, 2013), and comparing them to their undergraduate experience in general. More specifically, the study used the framework of Authentic Learning (Herrington, Reeves, \& Oliver, 2014) to examine how students' learning in ALCs was more authentic to experiences in the real world and would prepare them for future employment over traditional spaces like lecture halls and seminar rooms. One of the dominant themes that emerged was how instead of engaging in rich discussions getting students to participate in class often triggered students to produce endless "verbal diarrhea" which students hated and found unrealistic to real-world settings. However, students found that being in the ALCs helped to combat and avoid this unfortunate outcome. This paper presents case studies of students' lived experiences in their undergraduate degree, and their "prescriptions" and recommendations to instructors and other students on avoiding verbal diarrhea and encouraging meaningful discussions which will help students succeed in their life after graduation. The lessons learned from the study these may be useful for instructors using both ALCs and traditional teaching and learning spaces.

\section{Context}

This study took place in the context of an upper-year course on ethics in the workplace. It was open to all students in the third and fourth year of their undergraduate studies, and this iteration took place in an Active Learning Classroom (ALC) (See Figure 1). ALCs are re-imagined classrooms with a more aesthetically welcoming learning atmosphere compared to traditional lecture halls (Cotner et al., 2013), and allow instructors to incorporate more student-centered teaching and learning strategies shown to shape students' learning experiences (Baepler, Brooks, \& Walker, 2014). The classrooms can be high tech or low tech, contain flexible tables and seating or fixed round tables as it was in this particular classroom. All ALCs generally contain clear sightlines as the result of the flat open-concept circular configuration of the tables around the perimeter of the classroom. Students and instructors have reported that this decreases the physical and hierarchical barrier between the instructor, allowing for open communication and natural interactions to occur (Baepler et al., 2014). The instructor's podium is positioned an equal distance from all the tables in the room, permitting the instructor to quickly go to different students around the room and for the students to easily get the instructor's attention. Students have reported they feel more comfortable asking more questions to instructors in these rooms (Chen, 2015). Instructors have stated they become more enthusiastic about teaching by being in these classrooms (Beichner, 2014), and that attendance for classes held in these classrooms have shown to be higher than for classes in lecture halls (Horne, Murniati, Saichaie, Jesse, Florman, \& Ingram, 2014). A recent study by Chiu and Cheng (2017) not only reiterated these findings with students reporting positive and engaging learning experiences, but this trend occurred regardless of their achievement level in the course.

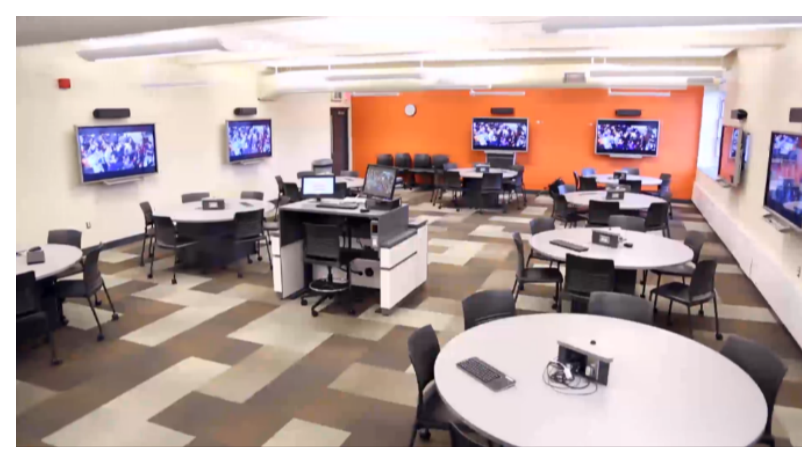

Figure 1

Image of an Active Learning Classroom 
The instructor of the course recognized the influential impact of the learning environment on the development and enactment of the curriculum, and noticeably changed the course to fit with the environment. This included turning lecture material into case studies which students would read and work through before coming to class, and dedicating the majority of class time to students interacting with peers to analyze and discuss the case studies. The class followed the format below 2-3 times each class:

1) Mini lecture: introducing the theories and an overview of the case studies

2) Small group discussions: students had to come up with a solution to the case

3) Whole class discussions: students shared with other groups their solutions

4) Debrief of the discussions: summarize and solidify discussion and case outcome

The instructor described wanting to create an environment for students to engage in realistic learning processes that would be applicable and transferable to any professional context. He did not want students to be spoon-fed information, as this would not do them any favours in the real world. Instead he pushed students to become more independent learners, learn more from their peers, and engage in challenging discussions they would face in their futures. This led to the use of the concept of Authentic Learning to frame the study.

\section{Authentic Learning Theories}

Each researcher has a slightly different interpretation of the concept of Authentic Learning but overall it is broadly defined as learning that takes place in the context of its use in the professional setting. It is viewed as a response to the traditional decontextualized nature of learning or even an alternative method of teaching (Meyers \& Nulty, 2009), providing rich resources and situating learning in the contexts of professional settings (Herrington et al., 2014). Students are immersed into the culture of professional practices, actively participating in tasks, and becoming competent members of their professional practice (Lave \& Wenger, 1991; Newmann, King, \& Carmichael, 2007). Some examples of how researchers have used this concept in their studies include Andersson and Andersson (2005) understanding and addressing the difficulty of Somali refugees in integrating into their community in Sweden, and Huang (2011) assessing students' ability to create an effective information system to help patients find local doctors in their area. In many of the studies using Authentic Learning, findings are mostly reported from the instructor's or researcher's perspectives; this study aims to shine a light on the students' perspectives and experiences and whether they thought the learning was authentic.

\section{Method}

A qualitative case study approach (Yin, 2013) was taken to interview both the instructor and ten of the students in the class on their lived experiences both in this course and in other courses. The instructor and students were interviewed three times over the course of the semester. They were asked a series of open ended questions pertaining to their experiences in the course and the learning environment, compared it to their experiences in other courses, and reflected on whether their learning experiences were authentic. Some examples of questions include: "Thinking about your learning/ teaching experiences so far, can you describe a typical learning/teaching experience? How do you feel about this approach to learning/teaching? In a job interview, what could you say about the type of learning you have experienced in this course that would help you (or students) in their future job or career?" All interviews were recorded, transcribed, and participants were given the opportunity to review the accuracy of the interview 
transcripts. Other artifacts such as USAT results, weekly exit cards, and observation notes were collected to triangulate the data.

From the large amounts of data, a thematic analysis (Braun \& Clarke, 2006) was first used to pull out emerging themes, one of which was the idea of "verbal diarrhea". All data related to this idea was drawn out from the data set to create a new data set. A narrative approach (Clandinin \& Connelly, 2000) was then used to analyze and present the findings from individual case studies, and general findings on the "prescriptions for verbal diarrhea" were generated from further thematic analyses on all the data collected.

\section{Findings}

Students' lived experiences and voices are presented in cases using excerpts from their interviews reflecting on both past and current experiences in participation and discussions. Three cases illustrate how verbal diarrhea was reduced and avoided in the course.

\section{Case 1: Configuration and Avoiding Verbal Diarrhea.}

Grace was a fourth year student in the Bachelor of Arts program with dreams of working in the Foreign Affairs with the Canadian government. She described her last 4 years of undergrad as uninspiring and filled with people spewing information at her, while being in this course was different: "It's because we are not participating but discussing. Normally people just have verbal diarrhea which is not a good time". She explained in other courses instructors would try to engage students in interactions by rewarding students who participated and this ended up encouraging students to say anything that came to their mind instead of building on each other's ideas. She dreaded when instructors or TAs would get each student to say what they thought about the readings or the content: "It's like oh my god! I have to think of three thoughts and throw them out! So I say something completely useless. Everyone talks but it's not building towards anything. Why are we doing this?"

Grace preferred the format and classroom configuration in this course with students thinking about their responses before the course, articulating their thoughts in small groups at their tables, and then presenting them to the entire class. With the clear sightlines of peers around the class, she could see who was talking and maintain eye contact with those she was interacting with. For her, this made the discussions actually discussions and not a competition of who can say the most. The other students in the study agreed with her, adding how the format made them feel safe, increased their comfort level to speak, to challenge others, and ask each other questions instead of only to the instructor.

Grace noted her learning experience in this course was very similar to the numerous workplaces environments she worked in: "This classroom mimics the workplace but is still educational, and that makes a lot of sense that we learn in this environment." The learning experience was setting her and her peers up for success in the real world: "It's very similar. No one is talking at me, we sit around a table like in a boardroom and everyone is talking just like this. It's mostly okay what do you guys think about it, let's talk, I want to hear your opinions." She added, "It makes more sense than a lecture hall setting," where some students always speak and some never speak. She gave an example of a co-worker, who broke down during a meeting when she tried to share her thoughts.

"Last year we were having a meeting and one girl burst into tears. She's like oh I'm sorry, I'm just really bad at speaking up for myself in a group setting like this. She's like this make me very anxious. She was disagreeing with what other people were saying but she didn't feel like she could because she wasn't 
comfortable with it. So if she would have had experience in this class maybe she shouldn't feel so anxious." (G1: 104-110)

\section{Case 2: Screens/ visual displays and learning to listen.}

Felicity was the opposite of Grace. She was a very outspoken and passionate fourth year student in the Bachelor of Arts program with the aim of becoming a teacher and then future principal. She was the first to talk in all of her other courses, often ignoring what others had to say and stating her thoughts as the only acceptable option. This worked very well in her other courses in lecture halls where she got full marks for participation, but as a future teacher and principal it was worrisome that she did little listening and proclaimed herself the "sage on the stage". She continued this way in this course until week four when something changed. The case was on displaying religious symbols in the workplace and an employee brought in his religious symbol which resembled the Swastika. Felicity had a personal connection with this symbol and had strong feelings about it but the discussion went a different way:

"In grade 12, I went to Poland and Germany to study World War II and the Holocaust. So when the prof talked about that symbol, I started to think how that still affects people and what's right from wrong and it didn't matter that it was a religious symbol for that guy but it offended everyone elsethat's wrong! It needed to be taken down. But then the discussion did not go the way I expected!"

Felicity described the screens in the classroom catching her eye before she let out her passionate response. Instead of students writing on their screens responses about removing the symbol, students were writing guidelines for preventing this from happening to any religious symbol. She overheard their conversations as well, and students were less focused on the Swastika and talking about how any symbol in the workplace could receive similar criticism:

"People didn't want to necessarily solve this particular case with the Swastika but make sure it does not happen in the future again for any religious symbol! So not thinking about the case individually or in isolation, but rather more abstractly and why or why shouldn't it happen again. I never really thought about that because coming in I thought well that is wrong and that's it."

Coming out of the discussion, Felicity was a changed person. From that week on and continuing over the weeks she stated, "I have learned to be respectful, to listen to others, be well spoken, and offer more questions than my opinion, which are all desirable qualities for a future teacher and principal."

\section{Case 3: Opportunity for discussions and becoming more open minded.}

Anna was a third-year student in the Nursing program, and falls in the middle range between Felicity's and Grace's thoughts on verbal diarrhea. She did not come into this class expecting it to be any different from her other courses where the instructors lectured and students listened. Having never voiced her opinions aloud in class nor hearing any of her peers share their thoughts either, she came in thinking, "Well why wouldn't everyone have the same opinion as me?" With a plethora of opportunities to speak in this class she found herself taken aback by how different everyone thought: "The discussions really show how different faculties are trained to think. It was an eye opener!"

Over the term, Anna began to think about case studies and topics in her own discipline and wondered whether other people had really thought the same as her. One specific case in her nursing courses was on whether to give patients who are Jehova's Witnesses blood transfusions. When she heard about the case in first year she thought it was 
really interesting but the instructor did not ask students for their thoughts and simply said "You give them blood" without any further explanation. She then heard the exact same case and solution repeatedly for the next three years and the refrain, "I hate that case with a passion- just give them the blood!" But after taking this course she said, "Now I see the consequences and some people think deeply about their values and you have to respect them. Putting all these case studies and discussions together has given us examples of how in real life they happen. I have become more opened to other people's thinking."

Another student Brie, a third year student in the Bachelor of Art's program, expanded on Anna's thoughts:

It's nice when you say a point and no one has a point to refute you, because you think you did a good job arguing it. But it's not real life. You will be dealing with people who are not going to agree with you or just argue with you, fight with you. So doing it in the classroom gives you the foundation for respectfully backing up your arguments.

The instructor's vital role. The students and instructors acknowledged the vital role the instructor had on making the overall learning environment a success, especially to combat verbal diarrhea. The following traits were important for the instructor to:

- $\quad$ Keep discussions on track

- $\quad$ Engage in small group discussions and orchestrate large group discussions

- Validate students' responses with more than "thanks, next"

- $\quad$ Ask for clarification on ideas that seemed off track to bring it back

- $\quad$ Ask for other students to provide input on responses

- Maintain a routine- 2-3 discussions every class
- $\quad$ Have a balance in who is talking

In referring to this final point, students explained how the instructor kept the conversations and discussions natural and fluid by allowing students to raise points when they came up and for the instructor to respond accordingly instead of following a strict script or designated time for who did the talking. As Brie stated, "It sucks when a prof just lectures or just makes you guys talk - we don't know if we are on the right track. There was a good balance in this course. This prof doesn't give you the answers but means, tools, to get to an answer. When it affects thousands of people you can't just say what's 'the right answer'."

Students found the instructor's constant presence and active involvement throughout the discussions very encouraging. They were less focused on coming up with a single long response, and more likely to go with the flow, ask questions as they came up, respond to their peers, and became more engaged in the content. Many even admitted coming into the course they were not very interested in the subject matter, but through immersion in the discussions they thought about the topics and ramifications of decisions more deeply.

\section{Prescription for Verbal Diarrhea}

In concluding this paper, prescriptions for combatting verbal diarrhea are offered to instructors who plan to incorporate participation and discussions into their courses whether they are in an ALC or a traditional teaching and learning space:

1) Ask yourself: Are students actually engaging in discussions?

2) Think about the space and making the best use of it, especially if you are not in an ideal learning environment. Is there a way for students to sit in a formation that is more conductive for discussions and more authentic to workplace settings? How can 
students share their ideas visually to peers in the classroom?

3) Be engaged throughout the discussions, especially the small group discussions. Interact with students and prompt them to think deeper about the issues.

4) $\mathrm{Be}$ mindful of practices (or misuse of practices) that might unintentionally encourage "verbal diarrhea," and have a plan on how to avoid this outcome. For example, are students only responding to you or are they responding to each other?

5) Think about how you would explain to students how the practices develop are transferable skills to the workplace.

In asking ourselves these questions, teaching strategies that may have been initially deemed as unsuccessful may actually result in successful and meaningful learning.

\section{References}

Andersson, S. B., \& Andersson, I. (2005). Authentic Learning in a Sociocultural Framework: A case study on non-formal learning. Scandinavian Journal of Educational Research, 49(4), 419-436.

Baepler, P., Brooks, D. C., \& Walker, J. D. (Eds.). (2014). Active Learning Spaces: New Directions for Teaching and Learning, Number 137. John Wiley \& Sons.

Beichner, R. J. (2014). History and evolution of active learning spaces. New Directions for Teaching and Learning, 2014(137), 9-16.

Braun, V., \& Clarke, V. (2006). Using thematic analysis in psychology. Qualitative research in psychology, 3(2), 77-101.
Chiu, P. H. P., \& Cheng, S. H. (2017). Effects of active learning classrooms on student learning: a two-year empirical investigation on student perceptions and academic performance. Higher Education Research \& Development, 36(2), 269-279.

Clandinin, D. J., \& Connelly, F. M. (2000). Narrative inquiry: Experience and story in qualitative research.

Chen, V. (2015).

Cotner, S., Loper, J., Walker, J. D., \& Brooks, D. C. (2013). " It's Not You, It's the Room"-Are the High-Tech, Active Learning Classrooms Worth It?. Journal of College Science Teaching, 42(6), 82-88.

Herrington, J., Reeves, T. C., \& Oliver, R. (2014). Authentic learning environments. In Handbook of research on educational communications and technology (pp. 401412). Springer New York.

Horne, S., Murniati, C. T., Saichaie, K., Jesse, M., Florman, J. C., \& Ingram, B. F. (2014). Using Qualitative Research to Assess Teaching and Learning in TechnologyInfused TILE Classrooms. New Directions for Teaching and Learning, 2014(137), 1726.

Huang, K. H. (2011). Learning in authentic contexts: Projects integrating spatial technologies and fieldwork. Journal of Geography in Higher Education, 35(4), 565-578.

Lave, J., \& Wenger, E. (1991). Situated learning: Legitimate peripheral participation. Cambridge university press.

Meyers, N. M., \& Nulty, D. D. (2009). How to use (five) curriculum design principles to align authentic learning environments, 
assessment, students' approaches to thinking and learning outcomes. Assessment \& Evaluation in Higher Education, 34(5), 565577.

Newmann, F. M., King, M. B., \& Carmichael, D. L. (2007). Authentic instruction and assessment: Common standards for rigor and relevance in teaching academic subjects. Prepared for the Iowa Department of Education.

Rubenson, K. (2010). Adult education overview. International Encyclopedia of Education, 111.

Yin, R. K. (2013). Case study research: Design and methods. Sage publications. 